\title{
Ovarian Mixed Germ Cell Tumor
}

National Cancer Institute

\section{Source}

National Cancer Institute. Ovarian Mixed Germ Cell Tumor. NCI Thesaurus. Code C8114.

An ovarian malignant germ cell tumor characterized by the presence of at least two different germ cell tumor components. The most common combination of germ cell tumors is dysgerminoma and yolk sac tumor. 